\title{
Review of the impact of renewable energy development on the environment and nature conservation in Southeast Asia
}

\author{
Santi Pratiwi ${ }^{1,2}$ (1) Nataly Juerges ${ }^{1}$ \\ ${ }^{1}$ Chair Group of Forest and Nature Conservation Policy, Georg-August-University Göttingen, Büsgenweg 3, 37077 Göttingen, Germany \\ ${ }^{2}$ Central Java Nature Conservation Office, Ministry of Environment and Forestry, Jl. Solo Gawok, Baki, Sukoharjo 57556, Central Java, \\ Indonesia
}

Received: 15 February 2020/Revised: 7 April 2020/Accepted: 29 April 2020/Published online: 16 May 2020

(C) The Author(s) 2020

\begin{abstract}
Renewable energy development is growing rapidly due to vast population growth and the limited availability of fossil fuels in Southeast Asia. Located in a tropical climate and within the Ring of Fire, this region has great potential for a transition toward renewable energy utilization. However, numerous studies have found that renewable energy development has a negative impact on the environment and nature conservation. This article presents a systematic literature review of the impact of renewable energy development on the environmental and nature conservation in Southeast Asia. Based on a review of 132 papers and reports, this article finds that the most reported negative impact of renewable energy development comes from hydropower, biofuel production, and geothermal power plants. Solar and wind power might also have a negative impact, albeit one less reported on than that of the other types of renewable energy. The impact was manifested in environmental pollution, biodiversity loss, habitat fragmentation, and wildlife extinction. Thus, renewable energy as a sustainable development priority faces some challenges. Government action in integrated policymaking will help minimize the impact of renewable energy development.
\end{abstract}

Keywords Renewable energy - Negative impacts . Environment $\cdot$ Nature conservation

Santi Pratiwi

spratiw@gwdg.de

\section{Introduction}

Demand for energy in Southeast Asia has rapidly increased due to rapid population growth and economic development (IEA 2019). Energy is crucial for fulfilling household needs and allowing industry and commercial trade. To allow further economic development, a reliable energy supply is necessary. However, dependence on fossil fuels is still high, especially in rural development (Erdiwansyah et al. 2019). The depletion of fossil fuels and climate change forces society to achieve sustainable development goals (SDGs). These goals point out that human development needs to be achieved in an environmentally sustainable way (Malerba 2019; Yadav et al. 2018). As part of climate change mitigation strategies, countries try to reduce fossil fuels and greenhouse gas emissions by transforming energy systems into sustainable systems, based on renewable energy, as one of the priorities of sustainable development (Karakosta et al. 2009; Khuong et al. 2019). Given the close relationship between climate change and energy use, renewable energy (RE) is a global solution for sustainable development (IEA 2019), offering environmentally friendly, low-emission technology (Malerba 2019).

In 2011, the United Nations secretary general launched the Sustainable Energy for All (SE4ALL) initiative, one of the objectives of which was to double the share of RE in the global mix by 2030 (IRENA 2018) to support one of the sustainable development goals for increased access to clean energy (Haselip et al. 2017). Most of the countries are actually well positioned to benefit from the Kyoto Protocol through Clean Development Mechanism (CDM) projects, especially for the development of RE (Lidula et al. 2007; Uddin et al. 2010). Countries have set a number of policies and mechanisms, especially at the ASEAN level 
under the ASEAN Plan of Action for Energy Cooperation (APAEC) in 2004-2009 (ACE 2015). This action plan has three priorities: energy efficiency and conservation, renewable energies, and clean coal technologies (Lidula et al. 2007). Under a regime of low-carbon measures, RE has been used and has grown extensively in the past few years in Southeast Asia (IEA 2019).

The Southeast Asia region consists of 11 countries, all of which (except for Timor-Leste) are also members of the Association of Southeast Asia Nations (ASEAN). ASEAN was established in 1967 and consists of Malaysia, the Philippines, Singapore, Thailand, Indonesia, Brunei, Vietnam, Laos, Myanmar, and Cambodia. Southeast Asian countries have a high RE potential due to tropical climate conditions and the fact that some are located within the Ring of Fire (Erdiwansyah et al. 2019; IEA 2019; Kumar 2016). In 2016, RE accounted for $26 \%$ of the total energy demand from biomass, hydropower, and wind, solar, and geothermal energy sources. Among those, hydropower was the biggest source of power generation, contributing $14 \%$ (IEA 2019). The Philippines ranks second in the world in terms of total geothermal electricity generation, while Indonesia ranks third. Thailand shows rapid annual growth in solar photovoltaic power, and the Mekong countries (Laos, Vietnam, Cambodia, and Myanmar) have abundant hydropower potential (Kumar 2016). Each country has targeted a different percentage use of RE to reach $23 \%$ of ASEAN energy mix by 2030 (Erdiwansyah et al. 2019).

Nevertheless, the region is not yet ready to globally contribute to RE development due to various challenges (Erdiwansyah et al. 2019; Lidula et al. 2007). There are large gaps between the ambitious target of installed capacity and the reality of RE development in Southeast Asia (Khuong et al. 2019). The selection of sustainable RE technologies often causes problems for policymakers and conflicts in society (Karakosta et al. 2009). Despite the importance of deploying renewable energy as a sustainable energy technology in Southeast Asia, there are many discussions about the impact of RE development on the environment and nature conservation worldwide. Paradoxically, RE development might increase biodiversity loss and wildlife extinction (Sánchez-Zapata et al. 2016). This review paper looks at the impact of RE development on the environment and nature conservation in Southeast Asia, while the most frequent studies concern RE potential and technical preparation in several Southeast Asian countries (ACE 2015; Ahmed et al. 2017; Erdiwansyah et al. 2019; IEA 2019; IRENA 2018; Kumar 2016; Lidula et al. 2007). Although many researchers have shown that RE will have a lower carbon footprint (Ahmed et al. 2017; Ismail et al. 2015; Petinrin and Shaaban 2015; Rana et al. 2016), there is still an impact on the environment and nature conservation, which is often miscalculated by the researcher and creates a cumulative impact on the future (Rudman et al. 2017). These trade-offs are often neglected by policymakers who experience knowledge gaps, since there is still little research on this topic worldwide. The importance of balancing trade-offs between RE development and environmental and natural conservation is likely to grow in the next decades, since the demand for RE is continuing to grow. Our study will help other researchers to assess the trade-offs from renewable energy development, the challenges, and its policy implications. This review makes relevant literature about the relationship between RE development and the environment easily available to policymakers. Thus, the government can formulate good planning and strong policy to achieve the goals of RE development without harming the environment and nature conservation.

\section{Methods}

\subsection{Study area}

RE resources are abundantly available in most Southeast Asian countries (Fig. 1). Located in tropical regions, almost all of the countries receive high daily solar radiation and are rich in water resources. Hydropower has the greatest potential in almost all countries, followed by wind and solar power. The biomass potential also varies due to differences in the production structures of agriculture, forestry, livestock, and industry. Indonesia, Malaysia, and Thailand lead the way in biomass development, which mainly comes from rice husks, bagasse, and palm oil waste (Lidula et al. 2007). Until 2016, the capacity and production of RE varied among countries. Countries with high water resources utilize hydropower to produce energy (the Philippines, Thailand, Malaysia, Indonesia, and Vietnam). Solar and wind power resources are also abundant and are expected to grow continuously in the coming decades (IEA 2019). The potential of geothermal energy varies from country to country depending on the presence of volcanic mountains, with the Philippines and Indonesia in leading positions (Kumar 2016; Lidula et al. 2007).

\subsection{Data collection}

This paper compiled the scientific literature on the impact of RE development on environmental and natural conservation in Southeast Asia. Information and data were obtained from published papers, databases, statistics, and reports. In the search for literature, various keywords and database sources were used. Studies were sought using keyword combinations from a first category (renewable energy, bioenergy, geothermal, hydropower, solar energy, 


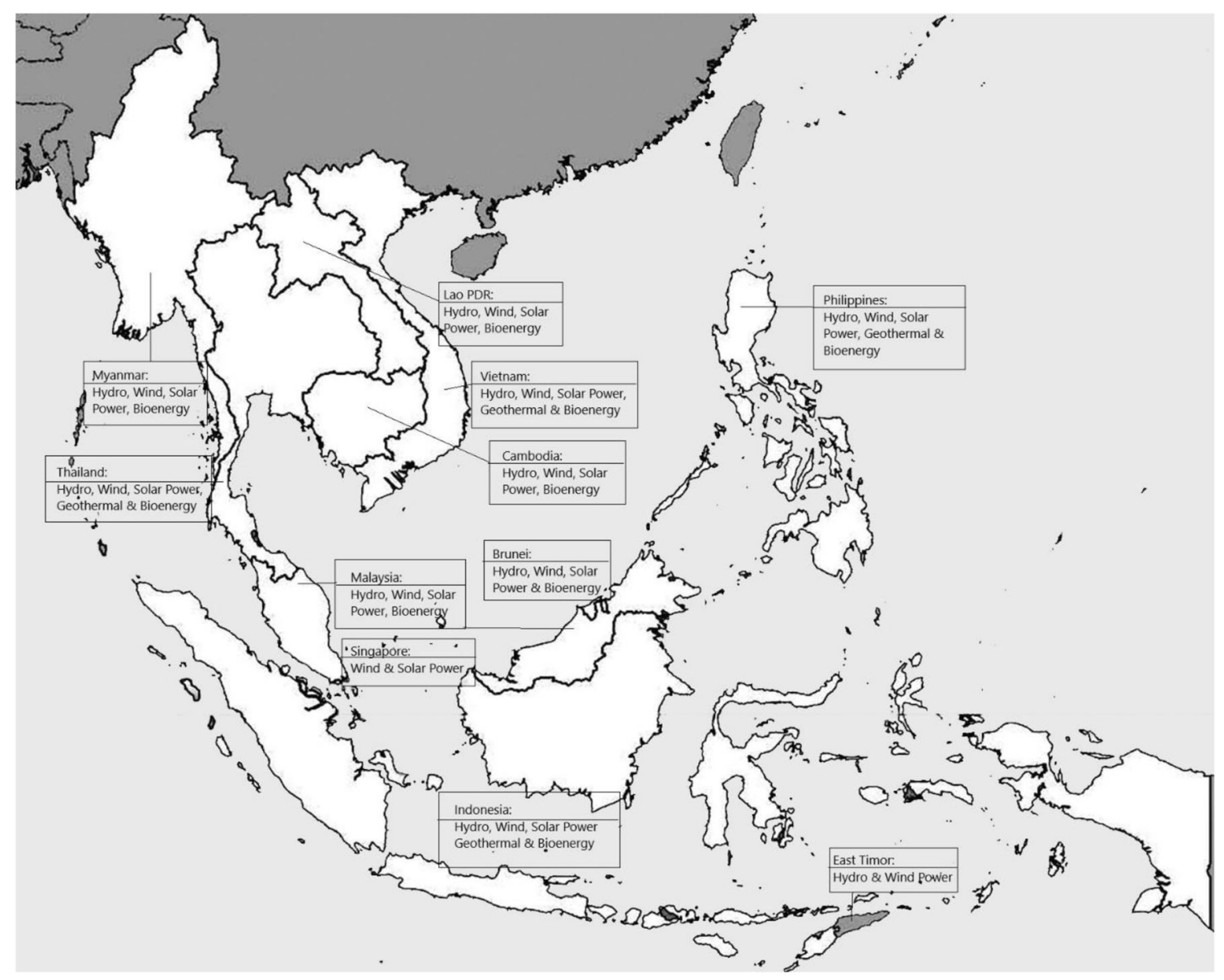

Fig. 1 Geographical distribution of RE potential in Southeast Asia

and wind power), a second category (conflicts, trade-off, impact, problem, and land use change), a third category (nature conservation, biodiversity, nature protection, forest, and environment), and a fourth category (Southeast Asia, Brunei, Cambodia, Timor-Leste, Indonesia, Laos, Malaysia, Myanmar, the Philippines, Singapore, Thailand, Vietnam, and ASEAN). The database sources of Google Scholar, Web of Science, Science Direct, and JSTOR Search were used as search platforms.

Of the 303 papers found through this literature search, 132 papers were cited in this paper due to their relevance to the review topic. We considered relevant papers only if they mentioned the trade-off or impact from the type of renewable energy on the environment and nature conservation. The type of impact analyzed included air, soil, and water pollution, greenhouse gas emissions, hydrological changes, landslide/soil erosion, deforestation, habitat fragmentation, and biodiversity loss, as summarized in Table 1 . We listed the relevant papers as a graph as shown in Fig. 2).

About 171 papers were considered irrelevant since they had no relation with the focus of our review and only discussed technical points. This article focuses on the most common type of RE (solar, wind, bioenergy, hydro, and geothermal) in Southeast Asia. Other types of RE technologies, such as ocean energy, were excluded, as they were still considered to be under development (Fig. 3).

\section{Environmental concerns}

An important reason for the development of RE is the desire to produce more energy while protecting the environment. While RE systems are generally less polluting than fossil fuels at their point of use (Liu et al. 2017), their environmental impact can be high at other stages in the life cycle of the system (Quek et al. 2018). There are several animal and plant species that could be disturbed by the development of RE. (See "Appendix 1" for more details.) Therefore, the environmental sustainability of RE depends on many aspects and not just on greenhouse gas emissions at the point of electricity generation (Quek et al. 2018).

\subsection{Solar power}

Solar power has a lower environmental impact than other RE technologies. However, researchers have found some 
Table 1 Summary of environmental and nature conservation trade-offs. Adapted from (Gasparatos et al. 2017)

\begin{tabular}{lllllllll}
\hline Type & $\begin{array}{l}\text { Air } \\
\text { pollution }\end{array}$ & $\begin{array}{l}\text { GHG } \\
\text { emissions }\end{array}$ & $\begin{array}{l}\text { Water } \\
\text { pollution }\end{array}$ & $\begin{array}{l}\text { Hydrological } \\
\text { change (flooding, } \\
\text { drought, } \\
\text { sedimentation, } \\
\text { etc.) }\end{array}$ & $\begin{array}{l}\text { Landslide/soil } \\
\text { erosion }\end{array}$ & $\begin{array}{l}\text { Soil } \\
\text { pollution/ } \\
\text { change }\end{array}$ & $\begin{array}{l}\text { Deforestation } \\
\text { Habitat loss/ } \\
\text { fragmentation }\end{array}$ & $\begin{array}{l}\text { Biodiversity } \\
\text { loss }\end{array}$ \\
\hline Solar & $\mathrm{X}$ & $\sqrt{ }$ & $\mathrm{X}$ & $\mathrm{X}$ & $\mathrm{X}$ & $\mathrm{X}$ & $?$ & $?$ \\
Wind & $?$ & $\mathrm{X}$ & $\mathrm{X}$ & $\mathrm{X}$ & $\mathrm{X}$ & $\mathrm{X}$ & $?$ & $?$ \\
Hydro & $\sqrt{ }$ & $\sqrt{ }$ & $\sqrt{ }$ & $\sqrt{ }$ & $\sqrt{ }$ & $\sqrt{ }$ & $\sqrt{ }$ & $\sqrt{ }$ \\
Bioenergy & $\sqrt{ }$ & $\sqrt{ }$ & $\sqrt{ }$ & $\sqrt{ }$ & $\mathrm{X}$ & $\sqrt{ }$ & $\sqrt{ }$ & $\sqrt{ }$ \\
Geothermal & $\sqrt{ }$ & $\mathrm{X}$ & $\sqrt{ }$ & $\sqrt{ }$ & $\sqrt{ }$ & $\sqrt{ }$ & $\sqrt{ }$ & $\sqrt{ }$ \\
\hline
\end{tabular}

$\sqrt{ }$ : Existing evidence and theoretical links

?: theoretical link but no existing evidence in this research area

$\mathrm{X}$ : no evidence found

\section{Cited Paper based on type of RE}

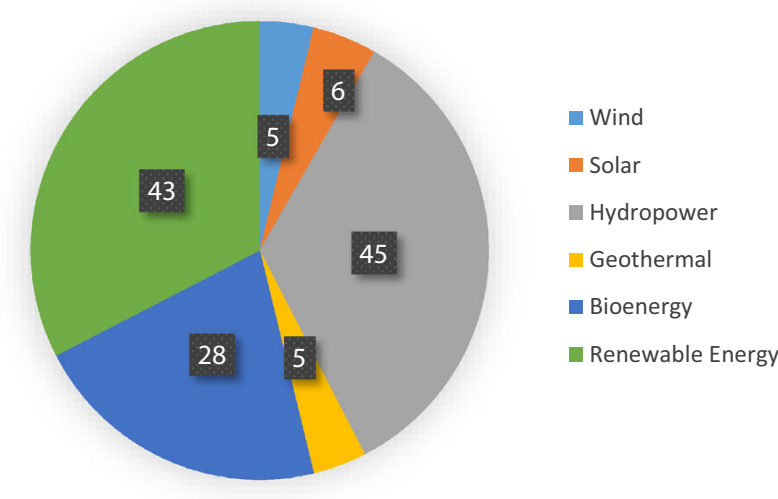

Fig. 2 The total of cited papers based on the type of renewable energy

Fig. 3 The total of cited papers based on the Southeast Asian countries impact of large-scale solar power on the environment. These trade-offs may occur during the construction, operation, and decommission of a utility-scale solar power plant. The manufacturing process of solar cells can produce dangerous waste (Delicado et al. 2016; Sánchez-Zapata et al. 2016). Solar power has the potential to increase water use and consumption (Rudman et al. 2017), dust and air pollution (Darwish et al. 2018), soil erosion, and land use change (Hernandez et al. 2014; Sánchez-Zapata et al. 2016), since solar power plants usually use large areas that need to be cleared of vegetation (Sánchez-Zapata et al. 2016). As a result of life cycle assessment in Singapore, solar photovoltaics contribute significantly to acidification potential (AP), eutrophication potential (EP), and human toxicity potential (HTP) (Quek et al. 2018). The highest environmental impact comes from solar energy in the form

\section{Total Paper based on Countries}

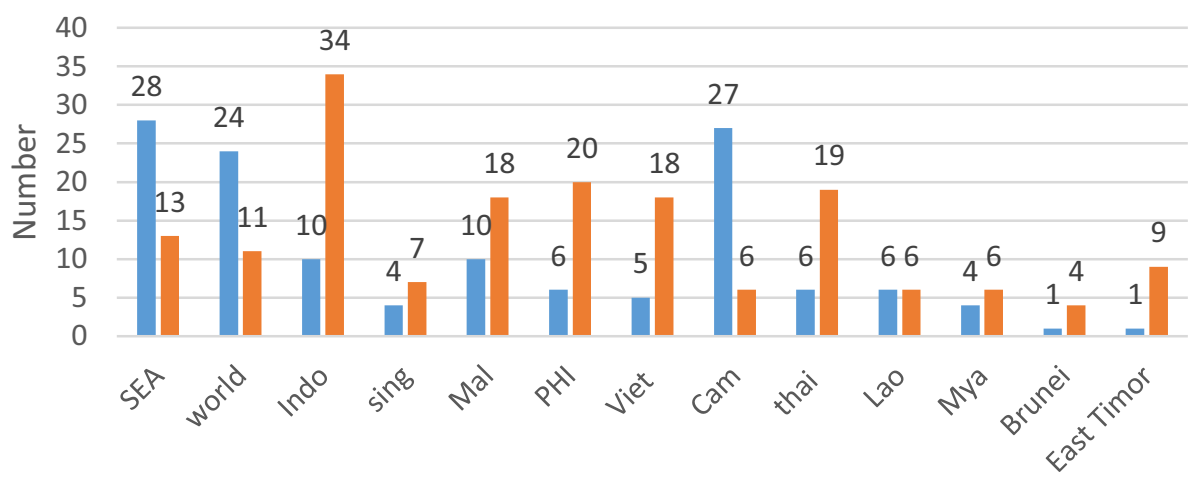

Southeast Asian Countries

- Cited Paper not Relevant Paper 
of HTP, which is mainly due to the manufacturing stage of the panels. The use of double-glazed windows and colortinted modules in building-integrated photovoltaics (BIPV) also produces more greenhouse gas emissions ( $\mathrm{Ng}$ and Mithraratne 2014).

\subsection{Wind power}

Wind power is considered the most environmentally friendly renewable technology. It has lower carbon emissions than other RE technologies. However, wind generators produce electric and magnetic fields, increasing the possibility that they will be struck by lightning (Saidur et al. 2011). Researchers have also found that wind turbines have some noise and visual impact on residences and wildlife (Delicado et al. 2016; Ladenburg 2009). The wind turbine also creates microclimate issues by changing the heat and moisture conditions around the wind farm (Rajewski et al. 2016; Sánchez-Zapata et al. 2016). The latest study found that wind turbines can induce weather modification with the possibility of climate change due to wind velocity, turbulence, and rough landscapes (Abbasi and Tabassum-Abbasi 2016). Recently, the governments of Thailand and Laos signed an agreement to build the Monsoon Wind Farm project near the Mekong River in southern Laos. Although the International Energy Agency (IEA) has confirmed that there will be no disruption to people's livelihoods and the environment, it will have an impact during the construction of plants (Saidur et al. 2011) that need to clear the land and remove all vegetation in the wind farm, creating soil erosion (Sánchez-Zapata et al. 2016).

\subsection{Bioenergy (biomass, biofuel, and biogas)}

For biogas, the generation of acidic substances during crop farming and combustion triggers acidification, while eutrophication impacts are associated with phosphorus concentration and nitrogen enrichment in water runoff from agricultural land (Quek et al. 2018). Air pollution has become a great environmental concern in Malaysia due to the combustion of wood and agricultural and animal waste (Shafie et al. 2011).

The conversion of land use had a significant effect in many cases, such as conflicts surrounding land and water resources. For example, the conversion of forests contributes $15-25 \%$ to global carbon emissions (Baral and Lee 2016). Indirect land use change for biofuel production can also add to greenhouse gas emissions, which are supposed to be reduced (Kumar et al. 2013). The whole chain of biofuel production (cultivation, processing, conversion, transport, and combustion) is considered to have more global warming potential than sequestered carbon
(Mukherjee and Sovacool 2014). A study on the greenhouse gas performance of bio-ethanol in Thailand showed that changing land use change from grassland to a cassava plantation causes more emissions than improving the yield of an existing plantation (Silalertruksa et al. 2009).

A study on the impact of the conversion of secondary peat swamp forest into mature palm oil plantations was conducted in Malaysia (Tonks et al. 2017), which found that the conversion decreased the swamp's carbon storage and water holding capacity. Peat lands are well known to house carbon reserves, which will cause greater carbon debt when they are converted into other land use. The carbon debt generated when carbon is emitted by converting native habitats (e.g., rainforest) into croplands will require years to be recaptured (Fargione et al. 2008). The land use change for biodiesel in Indonesia created the largest carbon debts (around 472.8-1743.7 $\mathrm{t} \mathrm{CO}_{2} \mathrm{ha}^{-1}$ ) due to the conversion of dense tropical forest into oil palm plantations. These plantations require another 59-220 years to offset the initial carbon debt (Achten and Verchot 2011). Another example is the establishment of palm oil plantations around the Danau Sentarum National Park, which has a negative effect by disrupting 96,519 ha of peat land, slowly releasing approximately 128 million tons of underground carbon into the atmosphere (Yuliani et al. 2000). Deforestation can lead to the diversion of waterways and swamps used as sources of freshwater for domestic needs. The villagers who live near palm oil plantations suffer from air pollution because of the burning of oil palm waste (Obidzinski et al. 2012). Others experienced soil erosion and changes in water quality and quantity, where the river floods in the rainy season and dries in the dry season. The increased use of insecticides and fertilizers to enhance biomass productivity may accelerate environmental degradation by causing a loss of biological control and water pollution for downstream communities (Baral and Lee 2016).

Furthermore, plantations of oil palm have grown in number, not only for biofuel production but also to meet demand from the food industry and other industries (Mukherjee and Sovacool 2014). Regarding the use of oil palm, the initial reason for the rapid development of oil palm plantations was the global demand of food (Susanti and Maryudi 2016). An IEA report shows that the use of oil is bigger in the industry than in the transportation sector (IEA 2019). Nevertheless, most of the Southeast Asian countries set themselves the goal of becoming the largest biodiesel producer as one of the valuable and promising alternatives to RE, especially Indonesia, Malaysia, and Thailand. For example, Malaysia retains $40 \%$ of its oil palm stock to produce biodiesel (Mekhilef et al. 2011), while Indonesia mandates that $20 \%$ of its oil palm stock be blended into diesel (Susanti and Maryudi 2016). This target 
converts large swaths of forest into oil palm in order to generate more money and achieve national biodiesel production. When this process occurs, claims of sustainable palm oil or environmentally friendly biodiesel are not valid, since there is an environmental disturbance (Mekhilef et al. 2011).

Although biomass fuels provide many advantages, they have a negative impact on the utilization of fossil fuels and fly ash during combustion (Verma et al. 2017). Biomass fuel cycles are often not greenhouse-gas-neutral because of the substantial production of PIC (products of incomplete combustion), which have a negative impact on human health in rural households in Cambodia (San et al. 2012). In Thailand, biomass power plants that produce less than $10 \mathrm{MW}$ using rice husk combustion systems have the potential to burden nearby villagers with environmental damage (air and water pollution due to black ash from smoke and dust), health problems (due to noise and smoke), and economic harm (due to lower farming productivity) (Yoo 2013). Furthermore, the burning of biomass energy and biogas emits $\mathrm{CO}_{2}, \mathrm{SO}_{2}$, and other greenhouse gas emissions, something also reported by other researchers (Andreae and Merlet 2001; Gadi et al. 2003; Pei-dong et al. 2007; Streets and Waldhoff 1998).

\subsection{Hydropower}

Several studies have reported the potential effects of hydropower project development in the Mekong River, including the Strategic Environmental Assessment (SEA) of Hydropower on the Mekong Mainstream (International Centre for Environmental Management 2010), the Lower Mekong Basin Development Plan 2 (MRC 2011), and the working paper on the economic, environmental, and social impacts of hydropower development in the Lower Mekong Basin (Intralawan et al. 2015). The Mekong River is one of the biggest rivers in Asia, flowing through six countries, from China through Myanmar, Laos, Thailand, and Cambodia, and ending in Vietnam. For years, hydropower projects have been altering the Mekong River Basin's riverine ecosystems (Sánchez-Zapata et al. 2016), which contain the world's largest inland fishery and provide food security (Hecht et al. 2019). Assessments have already concluded that the proposed dams would have significant effects on the movement of water and sediment, including changes in the timing and magnitude of seasonal flows. These cumulative impacts could destroy fisheries and riverside gardens, which would affect the livelihood of those who rely on river resources (Trung et al. 2018). Furthermore, sedimentation by mainstream dams would form a new delta (Trung et al. 2018). The planned dams will also cause erosion within the downstream floodplain and a $57 \%$ decrease in the wash load downstream.
Reservoir sediment trapping due to hydropower development could cause sediment starvation in downstream floodplains (Arias et al. 2014), altering the ecosystem services, aquatic productivity, and related ecological habitats (Kondolf et al. 2014). In Cambodia, hydropower dams change water levels in the lowland area, which may endanger riverine ecology and aquatic species (Dang et al. 2018). These studies, which are supported by other studies, find that the hydropower operations in the Upper Mekong Basin have caused considerable changes in the discharge regime in the Mekong River (Lauri et al. 2012; Piman et al. 2013; Räsänen et al. 2017) and dominate the changes in the floodplain sediment dynamics of the Mekong Delta (Manh et al. 2015). The discharge impact dampens the Mekong's annual flood pulse, thus reducing the sediment and nutrient transport for aquatic habitats (Lamberts 2008). The Mekong Delta experienced a decrease of up to $66 \%$ in the shoreline gradient rate (Li et al. 2017). Recently, a massive dam collapsed in Laos, resulting in casualties and loss of access to food and productive lowland paddy fields. This project diverts the waterway from one river to another through a tunnel, causing riverbank erosion and flooding, which negatively affects fisheries and drinking water (Barney 2007; International Rivers 2014; Shannon 2008). The extensive dam project in Laos also plays an important part in downstream vulnerability (Salmivaara et al. 2013) by reducing sediment flux, which affects biogeochemical cycles and ocean geochemistry (Robinson et al. 2007).

In addition, the Bakun Hydroelectric Project in Malaysia is a significant source of greenhouse gas emissions, especially carbon dioxide and methane, which arise from the microbial decomposition of submerged forests, vegetation, wildlife, and soil (Keong 2005). The dam project is also exposed to direct solar radiation and has a warming effect on the Bakun region. Large hydropower plants emit significant amounts of greenhouse gas $\left(\mathrm{CO}_{2}\right.$ and $\left.\mathrm{CH}_{4}\right)$ due to the decomposition of submerged biomass in the reservoir and due to energy-intensive activities such as construction work (Gagnon and Vate 1997). Indirectly, such dams would contribute to environmental degradation through logging, clearing of the catchment area, and road construction. These emit a substantial amount of greenhouse gases and affect hydrology, water quality, and river flow in a dam project in Borneo (Sovacool and Bulan 2012). There is also the special case of the proposed hydroelectric power project in Timor-Leste, which, due to the karstic nature of the area, would result in water leaking through underground channels. Hydrological diversion would also be responsible for the water level drop around the site (White et al. 2006). 


\subsection{Geothermal}

Hot spring water used as a tourist attraction in Laguna, the Philippines, due to its geothermal potential, is estimated to consume a large volume of groundwater. This could result in over-extraction, decreasing groundwater quantity and quality (Jago-on et al. 2017). The use of this geothermal energy for a hot spring area can also result in environmental damage, because the wastewater affects aquatic ecology near the geothermal power plants (Sánchez-Zapata et al. 2016). It is argued that geothermal power has the highest environmental impact, as it disrupts the geology in the site area (Asdrubali et al. 2015). The 1979 Lembata landslide and tsunami in Indonesia were primed by the hydrothermal alteration of rocks and soil in the geothermal environment. The area is located in a volcanic complex where the geothermal potential is evident due to numerous hot springs. The altered rocks and soils become loose, slightly lighter in weight, and change into clay minerals, which are more susceptible to landslides during the heavy rainfall season (Yudhicara et al. 2015). This was shown to be the case by the environmental impact assessment that was carried out in the Salak Geothermal Project. The assessment identified increasing surface soil erosion, increasing hydrogen sulfide in the air, temporary changes in stream water quality, and droughts during construction of the geothermal project (Slamet and Moelyono 2000). Geothermal power plants also have a social impact on the surrounding environment in the form of seismic activity, odor, and noise pollution. Moreover, the first-generation technology of geothermal power plants has a high potential for emissions because waste gases of $90 \% \mathrm{CO}_{2}$ are directly released (Evans et al. 2009).

\section{The nature conservation concern}

The production of RE can cause competition for land and water, resulting in an impact on biodiversity conservation (Popp et al. 2014; Sánchez-Zapata et al. 2016; Vijay et al. 2016). This is also related to deforestation, where land or forest needs to be cleared to build dams and reservoirs. In terms of nature conservation, this could lead to a loss of biodiversity (Sánchez-Zapata et al. 2016), habitat destruction (Urban et al. 2018), and a loss of terrestrial and aquatic habitats, which increases pressure on wildlife populations that are dependent on these habitats (Blake 2005; Mirumachi and Torriti 2012).

\subsection{Solar power}

Solar power is one of the most promising renewable energy technologies in Southeast Asia. All the countries in the region are in the stage of developing solar power, especially in the form of solar photovoltaics (PV). Reports or studies on the impact of solar PV on nature conservation are still relatively scarce in Southeast Asia. Often, the researcher miscalculates the cumulative and longtime impact from the solar power plant. However, researchers have found direct and indirect impacts of large-scale solar energy on biodiversity. These impacts could vary based on the solar plant design and technology type. The installation of solar power requires an area of many acres, which may result in habitat fragmentation and local biodiversity loss (Hernandez et al. 2014). The construction and solar power plants could affect the habitat and movement of local birds (Rudman et al. 2017). Solar plants can introduce exotic species invasions due to the opening of project area (Sánchez-Zapata et al. 2016). Solar power plants have also affected vegetation structures and types through land clearing and preparation (Rudman et al. 2017).

\subsection{Wind power}

The most negative impact of wind power is fauna collision with the wind turbine, as many researchers have reported (Drewitt and Langston 2006; Sovacool 2012). It was found that birds and bats have high mortality rates from hitting wind turbines (Maftouni 2017). These collisions might be caused by the influence of lighting and attraction from the wind power plant, tower design, weather conditions, and height of flight (Saidur et al. 2011). Not only local species of birds and bats were affected by the wind farm but also species that regularly migrated from the Northern to the Southern Hemisphere (Hull et al. 2015; Sánchez-Zapata et al. 2016). Another indirect impact from wind power plants is habitat fragmentation (Saidur et al. 2011) and demographic imbalance because it changes ecosystem function by disrupting not only plants and animals but also the human population (Delicado et al. 2016; Sánchez-Zapata et al. 2016). Offshore wind projects also have some negative effects on fish, marine mammals, birds, and seabed communities by creating noise, electromagnetic fields, and migration barriers (Dannheim et al. 2019; Haslett et al. 2018). Wind power projects have been realized in Thailand, the Philippines, and Vietnam. Recently, there has been a lack of studies (Green et al. 2016) or reports on the existing trade-offs of these projects.

\subsection{Bioenergy}

Currently, bioenergy in Indonesia is produced primarily from oil palm, which has been criticized as being a reason for deforestation, biodiversity loss, peat land drainage, and other socio-environmental issues (Abram et al. 2017; Gaveau et al. 2016; Obidzinski et al. 2012; Sharma et al. 
2018). Poorly planned bioenergy production will degrade natural forests, which are converted into monoculture plantations (Finco and Doppler 2010), by destroying biodiversity and, at the same time, increasing greenhouse gas emissions (Baral and Lee 2016). Forest conversion has been associated with the loss of biodiversity, including a decline in populations of endangered species such as the orangutan (in Borneo) and the Sumatran tigers (in Sumatra) (Obidzinski et al. 2012). Mostly, endangered species are threatened by fragmentation (Mukherjee and Sovacool 2014) and rapid extinction without the hope of regeneration (Koh and Wilcove 2008). In the riverine habitat, around 104 species of fish as well as a threatened crocodilian species, Tomistoma schegelii, have dwindled in population because of water pollution and loss of refuges and breeding sites caused by the conversion of peat swamp forests around the Danau Sentarum National Park into palm oil plantations. Moreover, 134 species (12 reptiles, 78 birds, and 11 mammals) are expected to become extinct as a result of dense forests changing into monoculture plantations (Yuliani et al. 2000). The loss of biodiversity and habitat will eventually lead to land conflicts and poverty from the loss of means of livelihood for the surrounding populations (Baral and Lee 2016).

\subsection{Hydropower}

There are four types of environmental impacts from the hydropower project in Malaysia: land clearing and deforestation, flooding and greenhouse gas emissions, changes in hydrology and water quality, and the impact of downstream aluminum smelting (Sovacool and Bulan 2011, 2012). The most relevant impact on natural conservation was the land clearing and deforestation of 70,000 hectares of forest for a reservoir area. Another project was estimated to have destroyed 500 million cubic meters of biomass, and the home to six rare and endangered fish species, 32 protected bird species, and six protected mammals, including herons, eagles, woodpeckers, silvered leaf monkeys, Borneo gibbons, Langurs, and flying squirrels, as well as more than 1600 protected plants (Keong 2005). Most hydropower projects change the existing land use to open reservoirs, which releases carbon, threatens biodiversity, and affects livelihoods in the areas around the project.

Furthermore, extensive hydropower development in the Mekong River Basin will decrease ecosystem productivity (Arias et al. 2014; Baran and Myschowoda 2009; Campbell et al. 2006; Kuenzer et al. 2013; Lamberts 2006). Developing hydropower to increase energy security has a negative impact on natural systems (Ho 2014). Future dam projects on the tributaries will change the seasonal flow (drought and flood), which will affect biodiversity, create environmental hotspots, and threaten the giant catfish and Irrawaddy dolphin in Laos and Myanmar (Intralawan et al. 2018). Enormous hydropower dams will also cause fragmentation, where the distribution and complexity of primary vegetation will be reduced ( $\mathrm{Li}$ et al. 2012). In Cambodia and Vietnam, the proposed hydropower projects will also cause major changes to river hydrology and sediment/nutrient dynamics, which will then affect the fisheries' productivity and floodplains in the coastal zone (Kummu and Sarkkula 2008; Kummu and Varis 2007; Lamberts 2008). With the shift in natural flow seasons, aquatic organisms will also be affected by the new flow conditions (Ngor et al. 2018). At least 89 migratory species, including 17 endemic and 14 endangered or critically endangered species, are threatened with extinction in the Mekong River system. This was also supported by a study in Laos, where the planned dams would affect fish diversity basin-wide, disrupting the river network and fish productivity as far as the Cambodian and Vietnamese floodplains (Ziv et al. 2012). Furthermore, the impact of changing aquatic ecosystems alters the natural food chain, which is critical to food security and the well-being of the Mekong River populations, as other researchers have observed (Baran and Myschowoda 2009; Hortle 2007; Intralawan et al. 2018; Ngor et al. 2018; Ziv et al. 2012). In the hydropower project in Timor-Leste, the site consists of a wetland ecosystem, karst nature area, and a tropical forest habitat, which is believed to have been destroyed, although a proper environmental assessment has not been conducted. The damage to the great diversity of aquatic plants, fish, and subsurface fauna needs to be mitigated, especially in the karst landscapes and existing caves, which are sensitive to human activities (White et al. 2006).

\subsection{Geothermal}

Another threat to forestry results from the utilization of geothermal power, for example, in Indonesia. Up to $42 \%$ of potential geothermal resources (more than 12GW) are located in protected forest areas. The Environmental Impact Assessment (EIA) was carried out twice in the geothermal project located on Mount Salak, which was later declared a national park (Mount Halimun Salak National Park). The assessment identified a decline in standing trees and a temporary disturbance to the wildlife habitat during exploration and construction (Slamet and Moelyono 2000). Although geothermal projects require only small tracts of land, there is an impact in the form of habitat and terrestrial ecosystem loss. Forest fragmentation, which is caused by the development of roads and other infrastructures to facilitate the development of geothermal projects, can result in habitat changes or destruction of existing flora and fauna (Tuyor et al. 2005). The opening 
process can provide great access to people (such as loggers, poachers, or settlers) and invasive species (Ashat and Ardiansyah 2012).

\section{Challenges and policy implications}

\subsection{Challenges for RE development}

To move forward along the path of RE, it is necessary to identify the challenges related to the impact on environmental and nature conservation and RE development in Southeast Asia.

\subsubsection{Financial challenges}

The high costs of technology have led to a slow development of RE in countries with limited financial resources (IEA 2019; Lidula et al. 2007; Rahmadi et al. 2017). The high potential of RE resources in Southeast Asia opens opportunities for many donors to support the development of RE projects. For example, the high potential of water resources attracts many foreign capital investors to build hydropower projects (Urban et al. 2013). Nevertheless, it is not clear whether large-scale hydropower projects are economically sustainable (Kim and Jung 2018). Various case studies have reported that the project countries remain dependent due to the failure of economic growth (Thomas 2005). For example, the projects of solar power installation for rural electrification supported by international donors (GTZ, AusAID, UNDP, USAID) in the Philippines showed their unsustainability by ceasing operation, or faced severe problems after the project finished. There was no technical and financial capacity to maintain RE projects, which then went to waste (Marquardt 2014). The development of many RE projects without assured financial backing has a negative impact on the environment, due to unsustainable project and maintenance issues.

\subsubsection{Institutional challenges}

The IEA also concluded that most of the countries have administrative and regulatory barriers, including gaps in the legal framework (IEA 2019) and a lack of authoritative institutions tasked with RE issues (Yadav et al. 2018). Inadequate policies and regulations that neglect sustainability in developing RE will lead to trade-offs with the environment and nature conservation (Erdiwansyah et al. 2019; Khuong et al. 2019). Even though there is an environmental impact assessment (EIA), weak coordination and planning among stakeholders does not provide effective harm prevention for nature and the environment. For example, in the case of mega hydropower development in the Lower Mekong Basin countries, an EIA was conducted, but there was a substantial impact on the environment (International Centre for Environmental Management 2010).

\subsubsection{Social challenges}

A lack of scientific studies and updated databases on the potential and status of RE can cause chaos in the planning process. These problems can lead to a lack of involvement by stakeholders, especially in local communities. A lack of awareness and involvement by local communities due to scarce information and the political situation (Erdiwansyah et al. 2019; Khuong et al. 2019) has resulted in the rejection of several RE development projects in countries such as Vietnam, Myanmar, and Indonesia. Some forms of RE, such as hydropower dams and geothermal energy, are still considered by local populations to be damaging to the environment. The Save Mekong campaign is a successful example of influencing the policy process and increasing public awareness of the environmental issues surrounding hydropower projects (Dore et al. 2012). In Thailand and Malaysia, RE is still considered to be immature, risky, and unproven (Sovacool 2010), while in Myanmar, resistance has often led to violence (Dore et al. 2012). Furthermore, these instances of rejection could cause an increase in consumption and the creation of subsidies and a general bias toward conventional energy technologies (IEA 2019).

\subsubsection{Technical challenges}

Some countries still have minimal sources and infrastructure and a lack of the skilled human resources that are needed to build RE projects. A lack of advanced knowledge in recent RE technology and innovation can have serious consequences for the environment and nature conservation. These consequences would be worse when there are limited financial resources that would lead to the irrelevant use of RE, for example, with low efficiency rates or low-quality equipment. Environmental sustainability can only be achieved through the deployment of efficient and affordable RE technologies (Kaygusuz 2012) and a wide range of approaches (IEA 2019). Insufficient grid capacity and extension represent a major bottleneck in the expansion of the market insertion of RE electricity. An example of this is Laos, which still has limited grid facilities and a technology-specific barrier (Lidula et al. 2007) (Table 2).

\subsection{Policy implications}

Currently, Southeast Asian countries are trying to reduce greenhouse gas emissions by reducing the utilization of fossil fuels and introducing more RE utilization. These objectives are in line with the SDG's targets of clean energy and climate action. To foster this change, countries are 
Table 2 Summary of important barriers

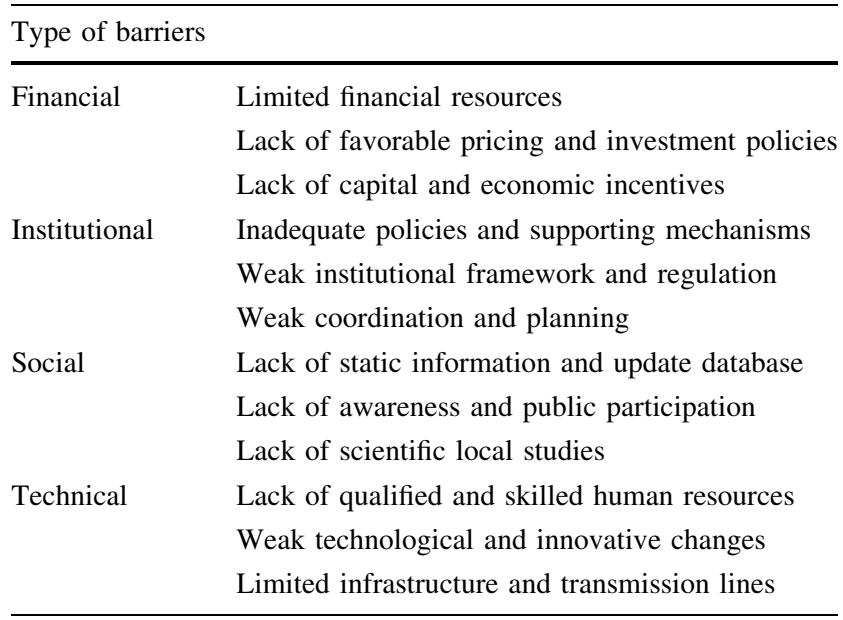

developing regulations, policies, plans, and supporting mechanisms to reach their own target of RE utilization (Erdiwansyah et al. 2019; Gill et al. 2018). Clean technologies definitely require energy resources complemented by advanced technology and materials (Brook and Bradshaw 2012). Together, these factors accelerate the damage to natural systems. Thus, there will be more challenges to the energy and economic systems, since these countries have committed to reducing greenhouse gas emissions (Tran et al. 2016). However, climate change does not seem to be the main reason for the pursuit of RE development by these countries. The deployment of RE technology is highly driven by political situations and different interests. Climate change mitigation and sustainable energy development have not yet been fully integrated in global climate governance (Blohmke 2014). For example, biofuel development in Indonesia, Malaysia, the Philippines, and Thailand is driven mainly by the need for energy security and socioeconomic development (Kumar et al. 2013), while air quality considerations do not seem to be the objective of the introduction of climate policy in Vietnam (Zimmer et al. 2015).

A mega hydropower project in the Lower Mekong Basin countries is considered to be the cause of the fragmentation of river systems, changing the ecosystem and the livelihood of the rural population. This leads to environmental and social costs, making these ambitious hydropower plans highly controversial and politically charged (Fu et al. 2010; Räsänen et al. 2012). In the Philippines, RE is utilized to secure the energy supply and to enhance energy access by means of rural electrification, while climate protection, environmental, and other sustainability concerns remain as driving factors (Marquardt et al. 2016). Large-scale energy infrastructure networks can decrease rather than increasing energy security, especially if there is international conflict (Sovacool 2009). There is a conflict of interest between the upstream and downstream countries along the Mekong River (Kuenzer et al. 2013). The Mekong elite decision makers directly and indirectly profit from the dams and put the majority of the rural poor at risk. This project also became a politically charged topic, in which many studies and assessment reports are biased and guided by the interests of their respective institutions. Recently, ASEAN has halted a large hydropower project due to its impact on the environment (Khuong et al. 2019).

In Vietnam, there is confusion about the overlapping strategies for green growth, sustainable development, and tackling climate change, including competing policies that favor different stakeholders' interests (Urban et al. 2018). There is significant tension between building the highest hydropower project in the region and safeguarding the great Irrawaddy River in Myanmar, though the country has tackled the costs of development and environmental integration (Erdiwansyah et al. 2019). Due to minimal RE sources and technology, Brunei and Singapore are still engaged in intensive research on RE potential. Despite the renewable portfolio standards in the Philippines and Thailand, investments in fossil fuels continue to be greater than investments in alternative sources (Lidula et al. 2007). In Indonesia, forest laws intended to stop the expansion of palm oil plantations have stunted (perhaps unintentionally) the development of geothermal power sources (Sovacool 2010). The regulatory frameworks were not harmonized and were inappropriate, leading to the conclusion that the region as a whole was "not yet ready" for RE development (Lidula et al. 2007).

Sustainable development needs good governance to be successful. Thus, government intervention is needed to overcome these challenges to the promotion of RE development in each country (Khuong et al. 2019). A shift must be made away from the state-centric geopolitics of mastering nature and toward a sustainability paradigm with a link between the economy and ecology (Saroch 2008). A sustainable energy policy formulation, with a strong deployment of RE, could minimize the challenges and make climate change mitigation policy more feasible (Erdiwansyah et al. 2019; Tran et al. 2016). It is also necessary to integrate long-term environmental, social, and economic sustainability targets in all RE plans and programs in the future. Furthermore, international donors could also support the countries by exploiting negative cost options, raising awareness for potential co-benefits, and financing through the CDM (Uddin et al. 2010; Zimmer et al. 2015). There are some RE mechanisms to support this, such as renewable portfolio standards, green power programs, public research and development expenditures, system benefit charges, investment tax credits, production tax credits, tendering, and feed-in tariffs in Europe and the USA (Sovacool 2010). Southeast Asian countries will also need to increase cooperation within the region in order to speed up the deployment of RE technologies through the ASEAN Power Grid (Erdiwansyah et al. 2019; IEA 2019). 
Table 3 Summary of important policy implications

\begin{tabular}{ll}
\hline $\begin{array}{c}\text { Policy } \\
\text { implications }\end{array}$ & $\begin{array}{l}\text { Adjust the competing policies and mechanisms } \\
\text { Reformulate overlapping and misdirect } \\
\text { development strategies } \\
\text { Harmonize conflicting regulation by different } \\
\text { interests }\end{array}$
\end{tabular}

This will help ASEAN countries incorporate higher percentages of RE. The expansion of energy supply from RE sources in Southeast Asia will result in socioeconomic and environmental benefits (Erdiwansyah et al. 2019; Huang et al. 2019) (Table 3).

\section{Conclusion}

Considering the trade-offs between RE development, environment, and nature conservation, it is clear that RE is not always green and sustainable. These trade-offs usually have further implications in social and economic consequences, especially for the livelihoods of local communities near the RE project areas. Therefore, it is also important to raise public awareness and knowledge regarding the deployment of RE. Further scientific research and evaluation is needed to better understand the socioeconomic impact of $\mathrm{RE}$ and mitigate the impact of $\mathrm{RE}$ development in Southeast Asia.

Acknowledgements Open Access funding provided by Projekt DEAL. The authors would like to acknowledge the German Academic Exchange Service (DAAD) in Bonn, Germany, for financial support under the Research Grant Scholarship Program.

\section{Compliance with ethical standards}

Conflict of interest The authors declare that they have no conflict of interest.

Open Access This article is licensed under a Creative Commons Attribution 4.0 International License, which permits use, sharing, adaptation, distribution and reproduction in any medium or format, as long as you give appropriate credit to the original author(s) and the source, provide a link to the Creative Commons licence, and indicate if changes were made. The images or other third party material in this article are included in the article's Creative Commons licence, unless indicated otherwise in a credit line to the material. If material is not included in the article's Creative Commons licence and your intended use is not permitted by statutory regulation or exceeds the permitted use, you will need to obtain permission directly from the copyright holder. To view a copy of this licence, visit http://creativecommons. org/licenses/by/4.0/.

\section{Appendix 1}

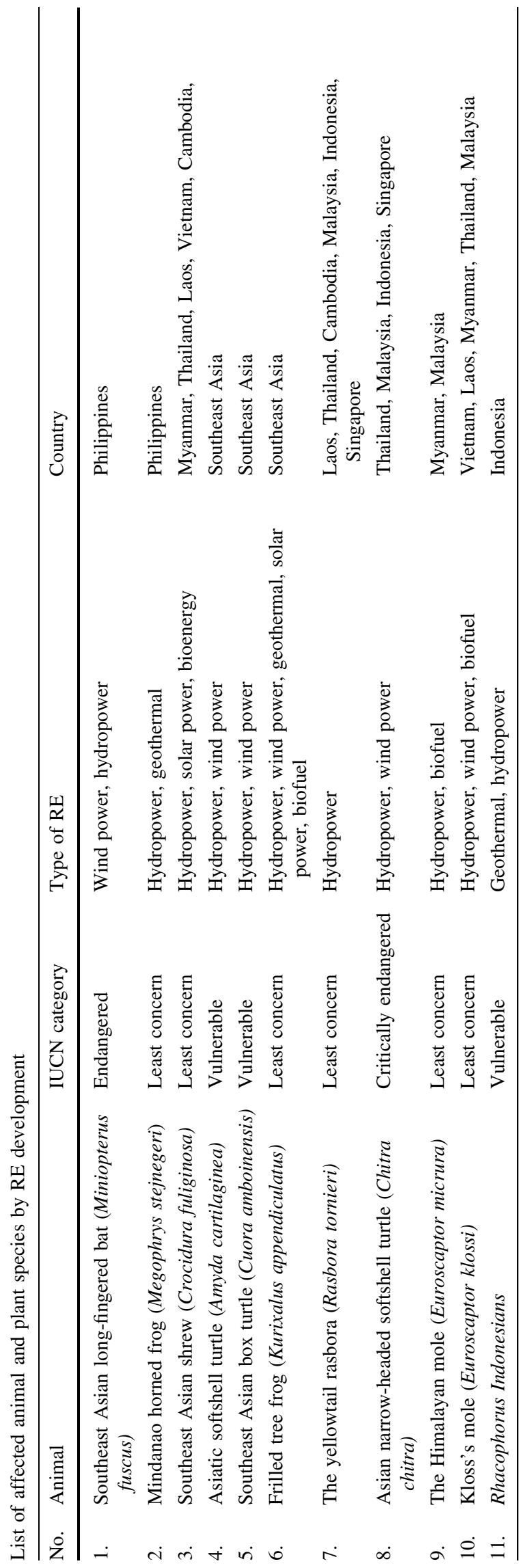




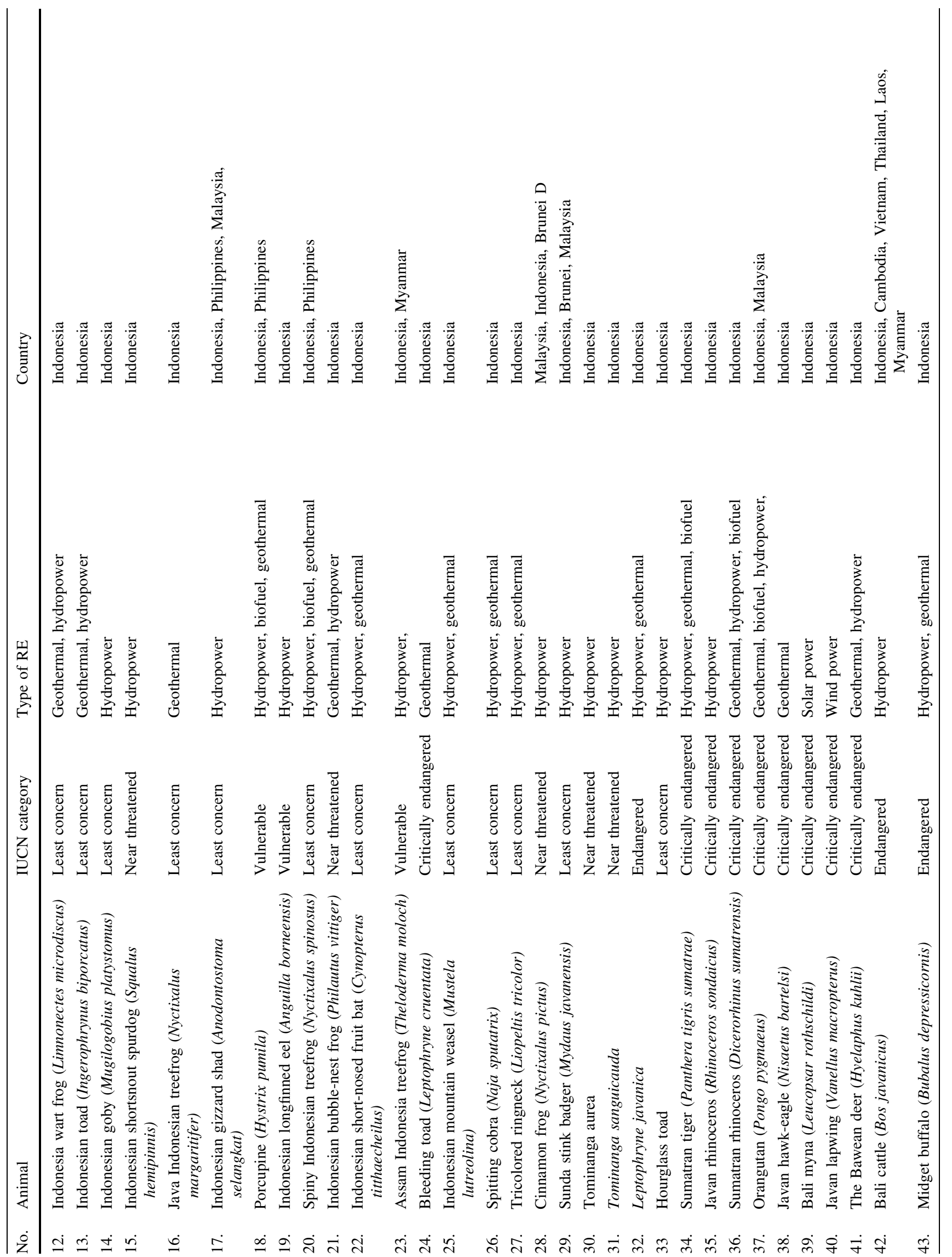




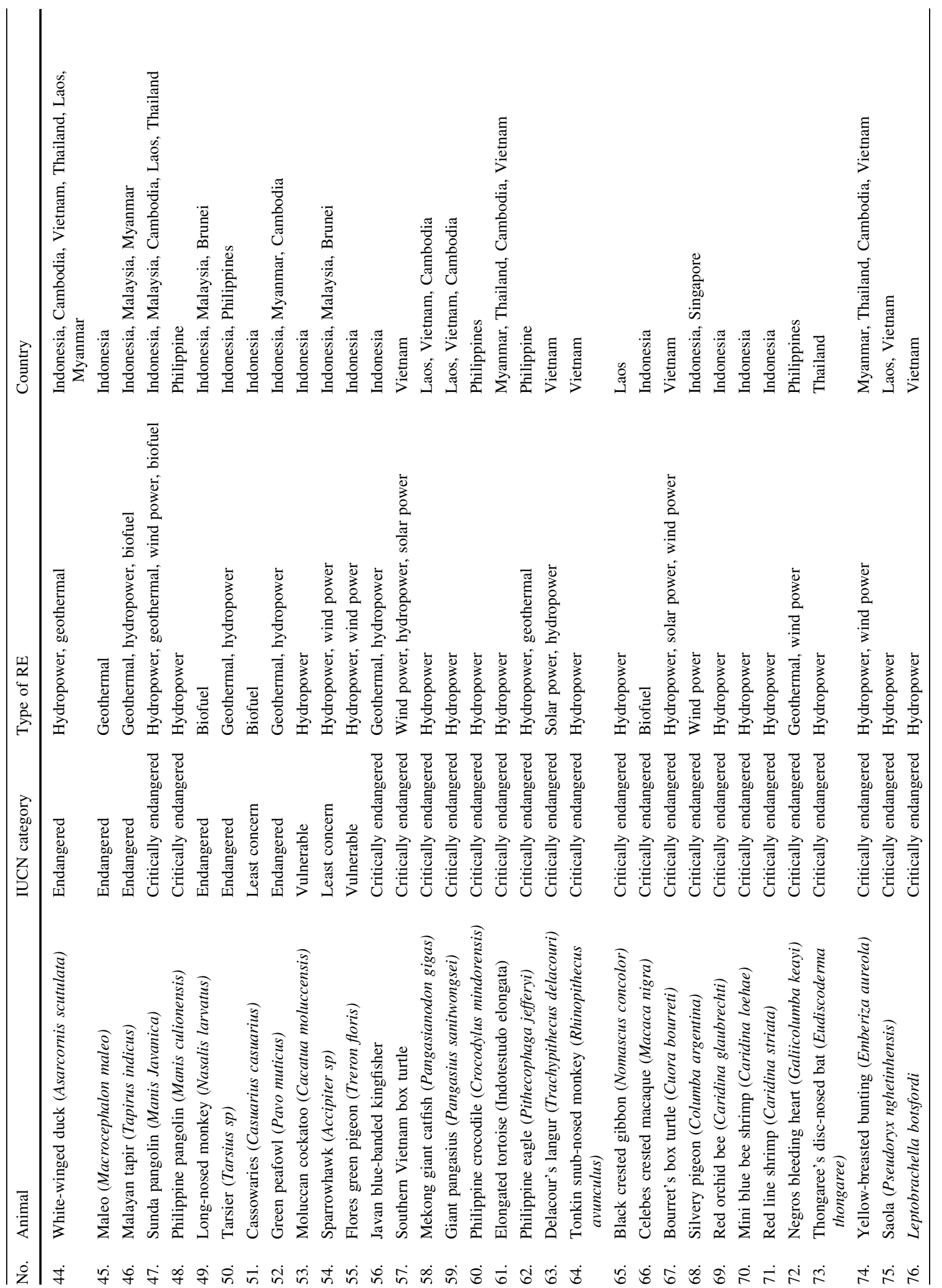




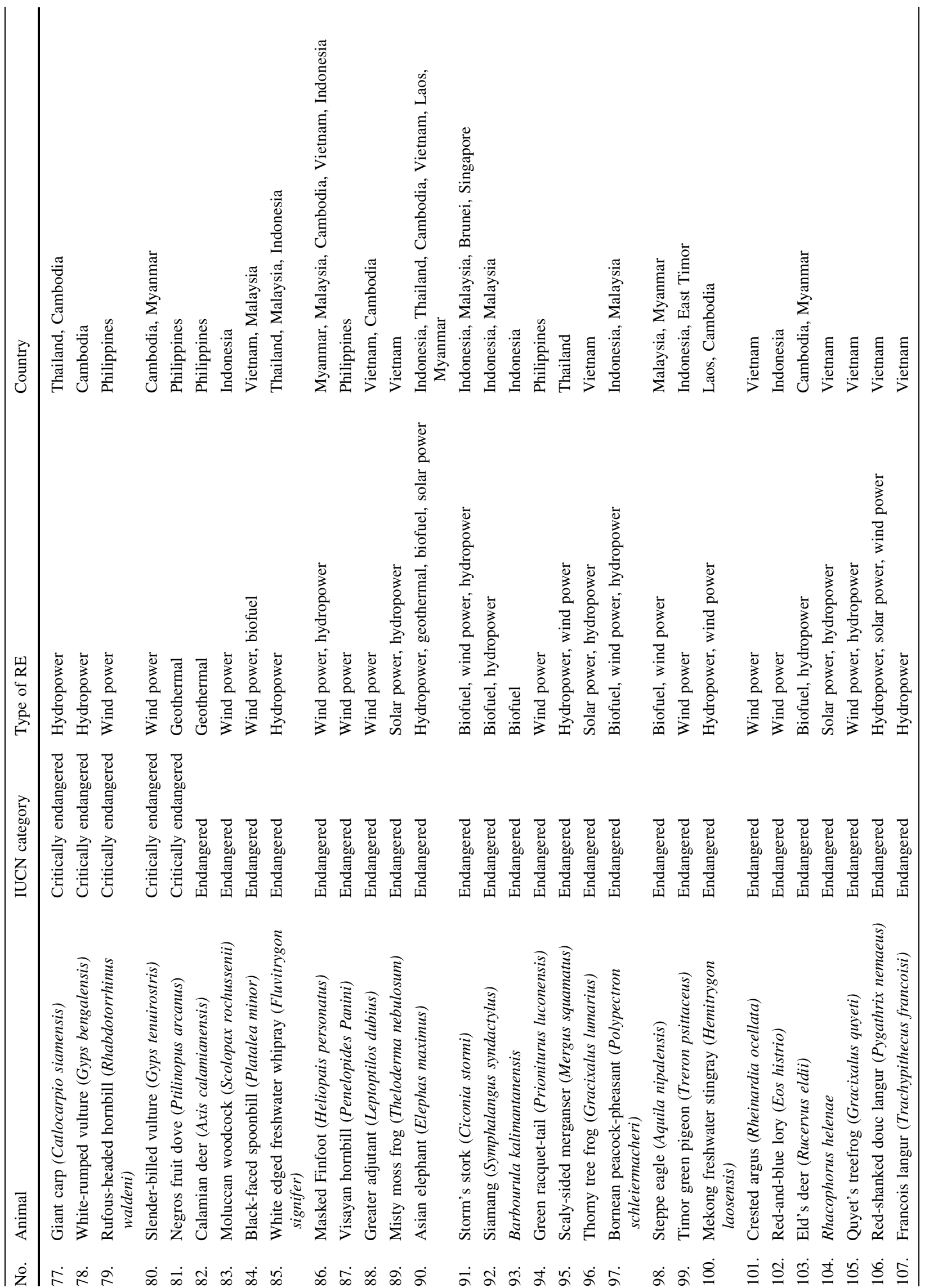




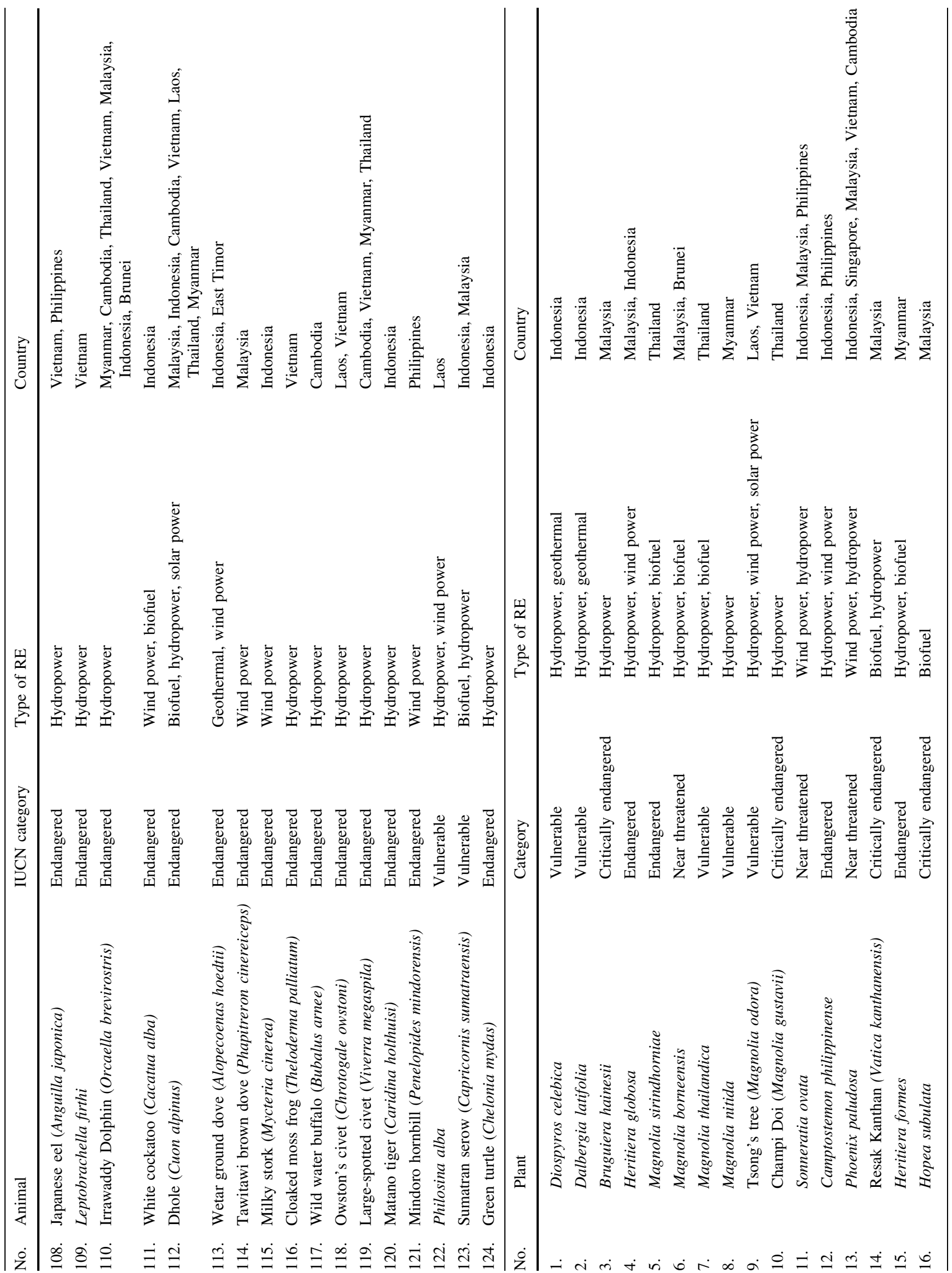




\section{References}

Abbasi SA, Tabassum-Abbasi AT (2016) Impact of wind-energy generation on climate: a rising spectre. Renew Sustain Energy Rev 59:1591-1598. https://doi.org/10.1016/j.rser.2015.12.262

Abram NK, Meijaard E, Wilson KA, Davis JT, Wells JA, Ancrenaz M, Budiharta S, Durrant A, Fakhruzzi A, Runting RK, Gaveau D, Mengersen K (2017) Oil palm-community conflict mapping in Indonesia: a case for better community liaison in planning for development initiatives. Appl Geogr 78:33-44. https://doi.org/ 10.1016/j.apgeog.2016.10.005

ACE (2015) ASEAN Plan of Action for Energy Cooperation (APAEC) 2016-2025; Phase 1' 2016-2020. ASEAN Centre for Energy (ACE). Jakarta, Indonesia

Achten WMJ, Verchot LV (2011) Implications of biodiesel-induced land-use changes for $\mathrm{CO}_{2}$ emissions: case studies in tropical America, Africa, and Southeast Asia. E\&S. https://doi.org/10. 5751/ES-04403-160414

Ahmed T, Mekhilef S, Shah R, Mithulananthan N, Seyedmahmoudian M, Horan B (2017) ASEAN power grid: a secure transmission infrastructure for clean and sustainable energy for South-East Asia. Renew Sustain Energy Rev 67:1420-1435. https://doi.org/ 10.1016/j.rser.2016.09.055

Andreae MO, Merlet P (2001) Emission of trace gases and aerosols from biomass burning. Global Biogeochem Cycles 15:955-966. https://doi.org/10.1029/2000GB001382

Arias ME, Cochrane TA, Kummu M, Lauri H, Holtgrieve GW, Koponen J, Piman T (2014) Impacts of hydropower and climate change on drivers of ecological productivity of Southeast Asia's most important wetland. Ecol Model 272:252-263. https://doi. org/10.1016/j.ecolmodel.2013.10.015

Asdrubali F, Baldinelli G, D’Alessandro F, Scrucca F (2015) Life cycle assessment of electricity production from renewable energies_ Review and results harmonization. Renew Sustain Energy Rev 42:1113-1122

Ashat A, Ardiansyah F (2012) Igniting the ring of fire: a vision for developing Indonesia's geothermal power. WWF-Indonesia, [Jakarta]

Baral H, Lee SM (2016) Sustainable bioenergy systems to restore and valorize degraded land. Center for International Forestry Research (CIFOR), Bogor

Baran E, Myschowoda C (2009) Dams and fisheries in the Mekong Basin. Aquat Ecosyst Health Manag 12:227-234. https://doi.org/ 10.1080/14634980903149902

Barney KD (2007) The trouble with tenure security in Laos. Watershed 12(2):57-64

Blake DJH (2005) A review of the Nam Theun 2: environmental assessment and management plan (EAMP) as it pertains to impacts on Xe Bang Fai Fisheries. https://www.internationalri vers.org/sites/default/files/attached-files/nt2fishimpacts.05.02.09. pdf. Accessed 12 Feb 2019

Blohmke J (2014) Technology complexity, technology transfer mechanisms and sustainable development. Energy Sustain Dev 23:237-246. https://doi.org/10.1016/j.esd.2014.09.003

Brook BW, Bradshaw CJA (2012) Strange bedfellows? Techno-fixes to solve the big conservation issues in southern Asia. Biol Cons 151:7-10. https://doi.org/10.1016/j.biocon.2011.10.007

Campbell IC, Poole C, Giesen W, Valbo-Jorgensen J (2006) Species diversity and ecology of Tonle Sap Great Lake, Cambodia. Aquat Sci 68:355-373. https://doi.org/10.1007/s00027-0060855-0

Dang TD, Cochrane TA, Arias ME, van Tri PD (2018) Future hydrological alterations in the Mekong Delta under the impact of water resources development, land subsidence and sea level rise.
J Hydrol Reg Stud 15:119-133. https://doi.org/10.1016/j.ejrh. 2017.12.002

Dannheim J, Bergström L, Birchenough SNR, Brzana R, Boon AR, Coolen JWP, Dauvin J-C, de Mesel I, Derweduwen J, Gill AB, Hutchison ZL, Jackson AC, Janas U, Martin G, Raoux A, Reubens J, Rostin L, Vanaverbeke J, Wilding TA, Wilhelmsson D, Degraer S (2019) Benthic effects of offshore renewables: identification of knowledge gaps and urgently needed research. ICES J Mar Sci 107:223. https://doi.org/10.1093/icesjms/fsz018

Darwish ZA, Kazem HA, Sopian K, Alghoul MA, Alawadhi H (2018) Experimental investigation of dust pollutants and the impact of environmental parameters on PV performance: an experimental study. Environ Dev Sustain 20:155-174. https://doi.org/10.1007/ s10668-016-9875-7

Delicado A, Figueiredo E, Silva L (2016) Community perceptions of renewable energies in Portugal: impacts on environment, landscape and local development. Energy Res Soc Sci 13:84-93. https://doi.org/10.1016/j.erss.2015.12.007

Dore J, Lebel L, Molle F (2012) A framework for analysing transboundary water governance complexes, illustrated in the Mekong Region. J Hydrol 466-467:23-36. https://doi.org/10. 1016/j.jhydrol.2012.07.023

Drewitt AL, Langston RHW (2006) Assessing the impacts of wind farms on birds. IBIS 148:29-42

Erdiwansyah Mamat R, Sani MSM, Sudhakar K (2019) Renewable energy in Southeast Asia: policies and recommendations. Sci Total Environ 670:1095-1102. https://doi.org/10.1016/j.scito tenv.2019.03.273

Evans A, Strezov V, Evans TJ (2009) Assessment of sustainability indicators for renewable energy technologies. Renew Sustain Energy Rev 13:1082-1088

Fargione J, Hill J, Tilman D, Polasky S, Hawthorne P (2008) Land clearing and the biofuel carbon debt. Science 319:1235-1238. https://doi.org/10.1126/science.1152747

Finco MVA, Doppler W (2010) Bioenergy and sustainable development: the dilemma of food security and climate change in the Brazilian savannah. Energy Sustain Dev 14:194-199. https://doi. org/10.1016/j.esd.2010.04.006

Fu B-J, Wu B-F, Lü Y-H, Xu Z-H, Cao J-H, Niu D, Yang G-S, Zhou Y-M (2010) Three Gorges Project: efforts and challenges for the environment. Prog Phys Geogr 34:741-754. https://doi.org/10. $1177 / 0309133310370286$

Gadi R, Kulshresta UC, Sarkar AK, Garg SC, Parashar DC (2003) Emissions of $\mathrm{SO}_{2}$ and $\mathrm{NO}_{\mathrm{x}}$ from biofuels in India. Tellus $\mathrm{B}$ 55:787-795. https://doi.org/10.1034/j.1600-0889.2003.00065.x

Gagnon L, Vate JF (1997) Greenhouse gas emission from hydropower. Energy Policy 25(1):7-13

Gasparatos A, Doll CNH, Esteban M, Ahmed A, Olang TA (2017) Renewable energy and biodiversity: implications for transitioning to a Green Economy. Renew Sustain Energy Rev 70:161-184. https://doi.org/10.1016/j.rser.2016.08.030

Gaveau DLA, Sheil D, Husnayaen Salim MA, Arjasakusuma S, Ancrenaz M, Pacheco P, Meijaard E (2016) Rapid conversions and avoided deforestation: examining four decades of industrial plantation expansion in Borneo. Sci Rep 6:32017. https://doi.org/ $10.1038 /$ srep32017

Gill AR, Viswanathan KK, Hassan S (2018) A test of environmental Kuznets curve (EKC) for carbon emission and potential of renewable energy to reduce green house gases (GHG) in Malaysia. Environ Dev Sustain 20:1103-1114. https://doi.org/ 10.1007/s10668-017-9929-5

Green RE, Langston RHW, McCluskie A, Sutherland R, Wilson JD (2016) Lack of sound science in assessing wind farm impacts on seabirds. J Appl Ecol 53:1635-1641. https://doi.org/10.1111/ $1365-2664.12731$ 
Haselip JA, Larsen TH, Ackom EK, Mackenzie GA, Christensen JM (2017) Reflections on experience with the global network on energy for sustainable development as a South-South global knowledge network. Energy Sustain Dev 36:37-43. https://doi. org/10.1016/j.esd.2016.11.002

Haslett JR, Garcia-Llorente M, Harrison PA, Li S, Berry PM (2018) Offshore renewable energy and nature conservation: the case of marine tidal turbines in Northern Ireland. Biodivers Conserv 27:1619-1638. https://doi.org/10.1007/s10531-016-1268-6

Hecht JS, Lacombe G, Arias ME, Dang TD, Piman T (2019) Hydropower dams of the Mekong River basin: a review of their hydrological impacts. J Hydrol 568:285-300. https://doi.org/10. 1016/j.jhydrol.2018.10.045

Hernandez RR, Easter SB, Murphy-Mariscal ML, Maestre FT, Tavassoli M, Allen EB, Barrows CW, Belnap J, Ochoa-Hueso R, Ravi S, Allen MF (2014) Environmental impacts of utilityscale solar energy. Renew Sustain Energy Rev 29:766-779. https://doi.org/10.1016/j.rser.2013.08.041

Ho E (2014) Unsustainable development in the Mekong: the price of hydropower. Consilience 12:63-76

Hortle KG (2007) Consumption of and the yield of fish and other aquatic animals in the Lower Mekong Basin. MRC Technical Paper No. 16 Mekong River Commission, Vientiane

Huang YW, Kittner N, Kammen DM (2019) ASEAN grid flexibility: preparedness for grid integration of renewable energy. Energy Policy 128:711-726. https://doi.org/10.1016/j.enpol.2019.01.025

Hull C, Bennett E, Stark E, Smales I, Lau J, Venosta M (eds) (2015) Wind and wildlife. Springer Netherlands, Dordrecht

IEA (2019) Southeast Asia Energy Outlook 2019. International Energy Agency. https://Southeast-Asia-Energy-Outlook-2019. pdf. Accessed 11 Mar 2020

International Rivers (2014) Failure to restore: an assessment of the impacts of the Theun-Hinboun hydropower dam projects on downstream communities in LAOS. https://www.internationalri vers.org/sites/default/files/attached-files/thhp_and_thxp_down stream_impacts_report_2014.pdf. Accessed 12 Feb 2019

Intralawan A, Wood D, Frankel R (2015) Working paper on economic, environmental and social impacts of hydropower development in the lower Mekong Basin. http://www.ftwatch.at/ wp-content/uploads/2015/10/Final-Report-on-Mekong-Hydro power-Development.pdf. Accessed 15 Feb 2019

Intralawan A, Wood D, Frankel R, Costanza R, Kubiszewski I (2018) Tradeoff analysis between electricity generation and ecosystem services in the lower Mekong Basin. Ecosyst Serv 30:27-35. https://doi.org/10.1016/j.ecoser.2018.01.007

IRENA (2018) Renewable energy statistics 2018. The International Renewable Energy Agency, Abu Dhabi

Ismail AM, Ramirez-iniguez R, Asif M, Munir AB, Muhammad SF (2015) Progress of solar photovoltaic in ASEAN countries: a review. Renew Sustain Energy Rev 48:399-412

Jago-on KAB, Siringan FP, Balangue-Tarriela R, Taniguchi M, Reyes YK, Lloren R, Peña MA, Bagalihog E (2017) Hot spring resort development in Laguna Province, Philippines: challenges in water use regulation. J Hydrol Reg Stud 11:96-106. https://doi. org/10.1016/j.ejrh.2015.11.020

Karakosta C, Doukas H, Psarras J (2009) Directing clean development mechanism towards developing countries' sustainable development priorities. Energy Sustain Dev 13:77-84. https:// doi.org/10.1016/j.esd.2009.04.001

Kaygusuz K (2012) Energy for sustainable development: a case of developing countries. Renew Sustain Energy Rev 16:1116-1126

Keong CY (2005) Energy demand, economic growth, and energy efficiency - the Bakun dam-induced sustainable energy policy revisited. Energy Policy 33:679-689. https://doi.org/10.1016/j. enpol.2003.09.017
Khuong PM, McKenna R, Fichtner W (2019) Analyzing drivers of renewable energy development in Southeast Asia countries with correlation and decomposition methods. J Clean Prod 213:710-722. https://doi.org/10.1016/j.jclepro.2018.12.192

Kim H, Jung TY (2018) Independent solar photovoltaic with Energy Storage Systems (ESS) for rural electrification in Myanmar. Renew Sustain Energy Rev 82:1187-1194. https://doi.org/10. 1016/j.rser.2017.09.037

Koh LP, Wilcove DS (2008) Is oil palm agriculture really destroying tropical biodiversity? Conserv Lett 1:60-64. https://doi.org/10. 1111/j.1755-263X.2008.00011.x

Kondolf GM, Rubin ZK, Minear JT (2014) Dams on the Mekong: cumulative sediment starvation. Water Resour Res 50:5158-5169. https://doi.org/10.1002/2013WR014651

Kuenzer C, Campbell I, Roch M, Leinenkugel P, Tuan VQ, Dech S (2013) Understanding the impact of hydropower developments in the context of upstream-downstream relations in the Mekong River Basin. Sustain Sci 8:565-584. https://doi.org/10.1007/ s11625-012-0195-Z

Kumar S (2016) Assessment of renewables for energy security and carbon mitigation in Southeast Asia: the case of Indonesia and Thailand. Appl Energy 163:63-70. https://doi.org/10.1016/j. apenergy.2015.11.019

Kumar S, Shrestha P, Abdul Salam P (2013) A review of biofuel policies in the major biofuel producing countries of ASEAN: production, targets, policy drivers and impacts. Renew Sustain Energy Rev 26:822-836. https://doi.org/10.1016/j.rser.2013.06. 007

Kummu M, Sarkkula J (2008) Impact of the Mekong river flow alteration on the Tonle Sap flood pulse. AMBIO J Hum Environ 37:185-192. https://doi.org/10.1579/0044-7447(2008)37\% 5b185:IOTMRF\% 5d2.0.CO;2

Kummu M, Varis O (2007) Sediment-related impacts due to upstream reservoir trapping, the Lower Mekong River. Geomorphology 85:275-293. https://doi.org/10.1016/j.geomorph.2006.03.024

Ladenburg J (2009) Visual impact assessment of offshore wind farms and prior experience. Appl Energy 86:380-387. https://doi.org/ 10.1016/j.apenergy.2008.05.005

Lamberts D (2006) The Tonle Sap Lake as a productive ecosystem. Int J Water Resour Dev 22:481-495. https://doi.org/10.1080/ 07900620500482592

Lamberts D (2008) Little impact, much damage: the consequences of Mekong River flow alterations for the Tonle Sap ecosystem: modern myths of the Mekong. Water and Development Publications-Helsinki University of Technology, pp 3-18

Lauri H, de Moel H, Ward PJ, Räsänen TA, Keskinen M, Kummu M (2012) Future changes in Mekong River hydrology: impact of climate change and reservoir operation on discharge. Hydrol Earth Syst Sci 16:4603-4619. https://doi.org/10.5194/hess-164603-2012

Li J, Dong S, Yang Z, Peng M, Liu S, Li X (2012) Effects of cascade hydropower dams on the structure and distribution of riparian and upland vegetation along the middle-lower Lancang-Mekong River. For Ecol Manage 284:251-259. https://doi.org/10.1016/j. foreco.2012.07.050

Li X, Liu JP, Saito Y, van Nguyen L (2017) Recent evolution of the Mekong Delta and the impacts of dams. Earth Sci Rev 175:1-17. https://doi.org/10.1016/j.earscirev.2017.10.008

Lidula NWA, Mithulananthan N, Ongsakul W, Widjaya C, Henson R (2007) ASEAN towards clean and sustainable energy: potentials, utilization and barriers. Renew Energy 32:1441-1452. https:// doi.org/10.1016/j.renene.2006.07.007

Liu X, Zhang S, Bae J (2017) The impact of renewable energy and agriculture on carbon dioxide emissions: investigating the environmental Kuznets curve in four selected ASEAN countries. 
J Clean Prod 164:1239-1247. https://doi.org/10.1016/j.jclepro. 2017.07.086

Malerba D (2019) Poverty-energy-emissions pathways: recent trends and future sustainable development goals. Energy Sustain Dev 49:109-124. https://doi.org/10.1016/j.esd.2019.02.001

Maftouni N, Yazdanjou R (2017) Effects of the conventional wind farms on environment. Conference Proceedings on International Conference on Environmental Science and Technology. Rhodes, Greece

Manh NV, Dung NV, Hung NN, Kummu M, Merz B, Apel H (2015) Future sediment dynamics in the Mekong Delta floodplains: impacts of hydropower development, climate change and sea level rise. Global Planet Change 127:22-33. https://doi.org/10. 1016/j.gloplacha.2015.01.001

Marquardt J (2014) How sustainable are donor-driven solar power projects in remote areas? J Int Dev 26:915-922. https://doi.org/ $10.1002 /$ jid.3022

Marquardt J, Steinbacher K, Schreurs M (2016) Driving force or forced transition? J Clean Prod 128:22-33. https://doi.org/10. 1016/j.jclepro.2015.06.080

Mekhilef S, Siga S, Saidur R (2011) A review on palm oil biodiesel as a source of renewable fuel. Renew Sustain Energy Rev 15:1937-1949. https://doi.org/10.1016/j.rser.2010.12.012

Mirumachi N, Torriti J (2012) The use of public participation and economic appraisal for public involvement in large-scale hydropower projects: case study of the Nam Theun 2 Hydropower Project. Energy Policy 47:125-132. https://doi.org/10. 1016/j.enpol.2012.04.034

MRC (2011) Assessment of Basin-wide development scenarios. Basin Development Programme, Phase 2. Mekong River Commission (MRC), Lao PDR

Mukherjee I, Sovacool BK (2014) Palm oil-based biofuels and sustainability in southeast Asia: a review of Indonesia, Malaysia, and Thailand. Renew Sustain Energy Rev 37:1-12. https://doi. org/10.1016/j.rser.2014.05.001

Ng PK, Mithraratne N (2014) Lifetime performance of semitransparent building-integrated photovoltaic (BIPV) glazing systems in the tropics. Renew Sustain Energy Rev 31:736-745. https://doi.org/10.1016/j.rser.2013.12.044

Ngor PB, Legendre P, Oberdorff T, Lek S (2018) Flow alterations by dams shaped fish assemblage dynamics in the complex Mekong3 S river system. Ecol Ind 88:103-114. https://doi.org/10.1016/j. ecolind.2018.01.023

Obidzinski K, Andriani R, Komarudin H, Andrianto A (2012) Environmental and social impacts of oil palm plantations and their implications for biofuel production in Indonesia. E\&S. https://doi.org/10.5751/ES-04775-170125

Pei-dong Z, Guomei J, Gang W (2007) Contribution to emission reduction of $\mathrm{CO}_{2}$ and $\mathrm{SO}_{2}$ by household biogas construction in rural China. Renew Sustain Energy Rev 11:1903-1912. https:// doi.org/10.1016/j.rser.2005.11.009

Petinrin JO, Shaaban M (2015) Renewable energy for continuous energy sustainability in Malaysia. Renew Sustain Energy Rev 50:967-981. https://doi.org/10.1016/j.rser.2015.04.146

Piman T, Lennaerts T, Southalack P (2013) Assessment of hydrological changes in the lower Mekong Basin from Basin-Wide development scenarios. Hydrol Process 27:2115-2125. https:// doi.org/10.1002/hyp.9764

Popp J, Lakner Z, Harangi-Rákos M, Fári M (2014) The effect of bioenergy expansion: food, energy, and environment. Renew Sustain Energy Rev 32:559-578. https://doi.org/10.1016/j.rser. 2014.01.056

Quek A, Ee A, Ng A, Wah TY (2018) Challenges in environmental sustainability of renewable energy options in Singapore. Energy Policy 122:388-394. https://doi.org/10.1016/j.enpol.2018.07.055
Rahmadi A, Hanifah H, Kuntjara H (2017) Renewable energy in ASEAN: an investment guidebook. The Habibie Center, Jakarta

Rajewski DA, Takle ES, Prueger JH, Doorenbos RK (2016) Toward understanding the physical link between turbines and microclimate impacts from in situ measurements in a large wind farm. J Geophys Res Atmos 121:13392-13414. https://doi.org/10. 1002/2016JD025297

Rana R, Ingrao C, Lombardi M, Tricase C (2016) Greenhouse gas emissions of an agro-biogas energy system: estimation under the renewable energy directive. Sci Total Environ 550:1182-1195. https://doi.org/10.1016/j.scitotenv.2015.10.164

Räsänen TA, Koponen J, Lauri H, Kummu M (2012) Downstream hydrological impacts of hydropower development in the upper Mekong Basin. Water Resour Manag 26:3495-3513. https://doi. org/10.1007/s11269-012-0087-0

Räsänen TA, Someth P, Lauri H, Koponen J, Sarkkula J, Kummu M (2017) Observed river discharge changes due to hydropower operations in the Upper Mekong Basin. J Hydrol 545:28-41. https://doi.org/10.1016/j.jhydrol.2016.12.023

Robinson RAJ, Bird MI, Oo NW, Hoey TB, Aye MM, Higgitt DL, Swe A, Tun T, Win SL (2007) The Irrawaddy river sediment flux to the indian ocean: the original nineteenth-century data revisited. J Geol 115:629-640. https://doi.org/10.1086/521607

Rudman J, Gauche P, Esler K (2017) Direct environmental impacts of solar power in two arid biomes: an initial investigation. S Afr J Sci 113:1-3

Saidur R, Rahim NA, Islam MR, Solangi KH (2011) Environmental impact of wind energy. Renew Sustain Energy Rev 15:2423-2430. https://doi.org/10.1016/j.rser.2011.02.024

Salmivaara A, Kummu M, Keskinen M, Varis O (2013) Using global datasets to create environmental profiles for data-poor regions: a case from the Irrawaddy and Salween River Basins. Environ Manag 51:897-911. https://doi.org/10.1007/s00267-013-0016-x

San V, Sriv T, Spoann V, Var S, Seak S (2012) Economic and environmental costs of rural household energy consumption structures in Sameakki Meanchey district, Kampong Chhnang Province, Cambodia. Energy 48:484-491. https://doi.org/10. 1016/j.energy.2012.10.017

Sánchez-Zapata JA, Clavero M, Carrete M, DeVault TL, Hermoso V, Losada MA, Polo MJ, Sánchez-Navarro S, Pérez-García JM, Botella F, Ibáñez C, Donázar JA (2016) Effects of renewable energy production and infrastructure on wildlife. In: Mateo R, Arroyo B, Garcia JT (eds) Current trends in wildlife research, vol 1. Springer, Cham, pp 97-123

Saroch E (2008) Chapter 10: Mapping the Mekong Basin: geopolitical imaginations and contestations. Environmental Security and Justice in the Indian Ocean Region. In: Doyle T, Risely M (eds) Crucible for survival. Rutgers University Press

Shafie SM, Mahlia TMI, Masjuki HH, Andriyana A (2011) Current energy usage and sustainable energy in Malaysia: a review. Renew Sustain Energy Rev 15:4370-4377. https://doi.org/10. 1016/j.rser.2011.07.113

Shannon L (2008) Power surge: the impacts of rapid dam development in Laos. International Rivers, Vientiane

Sharma R, Nehren U, Rahman S, Meyer M, Rimal B, Aria Seta G, Baral H (2018) Modeling Land Use and Land Cover Changes and Their Effects on Biodiversity in Central Kalimantan, Indonesia. Land 7:57. https://doi.org/10.3390/land7020057

Silalertruksa T, Gheewala SH, Sagisaka M (2009) Impacts of Thai bio-ethanol policy target on land use and greenhouse gas emissions. Appl Energy 86:S170-S177. https://doi.org/10.1016/ j.apenergy.2009.05.010

Slamet U, Moelyono DG (eds) (2000) Maximizing community benefits and minimizing environmental impacts in the Gunung Salak Geothermal Project, Indonesia 
Sovacool BK (2009) Reassessing energy security and the TransASEAN natural gas pipeline network in Southeast Asia. Pac Aff 82:467-486. https://doi.org/10.5509/2009823467

Sovacool BK (2010) A comparative analysis of renewable electricity support mechanisms for Southeast Asia. Energy 35:1779-1793. https://doi.org/10.1016/j.energy.2009.12.030

Sovacool BK (2012) The avian and wildlife costs of fossil fuels and nuclear power. J Intergrative Environ Sci 9(4):255-278

Sovacool BK, Bulan LC (2011) Behind an ambitious megaproject in Asia: the history and implications of the Bakun hydroelectric dam in Borneo. Energy Policy 39:4842-4859. https://doi.org/10. 1016/j.enpol.2011.06.035

Sovacool BK, Bulan LC (2012) Energy security and hydropower development in Malaysia: the drivers and challenges facing the Sarawak Corridor of Renewable Energy (SCORE). Renew Energy 40:113-129. https://doi.org/10.1016/j.renene.2011.09. 032

Streets DG, Waldhoff ST (1998) Biofuel use in Asia and acidifying emissions. Energy 23(12):1029-1042

Susanti A, Maryudi A (2016) Development narratives, notions of forest crisis, and boom of oil palm plantations in Indonesia. For Policy Econ 73:130-139. https://doi.org/10.1016/j.forpol.2016. 09.009

Thomas JJ (2005) Kerala's industrial backwardness: a case of path dependence in industrialization? World Dev 33:763-783. https:// doi.org/10.1016/j.worlddev.2004.12.002

Tonks AJ, Aplin P, Beriro DJ, Cooper H, Evers S, Vane CH, Sjögersten S (2017) Impacts of conversion of tropical peat swamp forest to oil palm plantation on peat organic chemistry, physical properties and carbon stocks. Geoderma 289:36-45. https://doi.org/10.1016/j.geoderma.2016.11.018

Tran T, Fujimori S, Masui T (2016) Realizing the intended nationally determined contribution: the role of renewable energies in Vietnam. Energies 9:587. https://doi.org/10.3390/en9080587

Trung LD, Duc NA, Nguyen LT, Thai TH, Khan A, Rautenstrauch K, Schmidt C (2018) Assessing cumulative impacts of the proposed Lower Mekong Basin hydropower cascade on the Mekong River floodplains and Delta-overview of integrated modeling methods and results. J Hydrol. https://doi.org/10.1016/j.jhydrol.2018. 01.029

Tuyor JB, de Jesus AC, Medrano RS, Garcia JRD, Salinio SM, Santos LS (2005) Impact of geothermal well testing on exposed vegetation in the Northern Negros Geothermal Project, Philippines. Geothermics 34:252-265. https://doi.org/10.1016/j. geothermics.2004.09.004

Uddin SN, Taplin R, Yu X (2010) Towards a sustainable energy future-exploring current barriers and potential solutions in
Thailand. Environ Dev Sustain 12:63-87. https://doi.org/10. 1007/s10668-008-9180-1

Urban F, Nordensvärd J, Khatri D, Wang Y (2013) An analysis of China's investment in the hydropower sector in the Greater Mekong Sub-Region. Environ Dev Sustain 15:301-324. https:// doi.org/10.1007/s10668-012-9415-Z

Urban F, Siciliano G, Wallbott L, Lederer M, Dang Nguyen A (2018) Green transformations in Vietnam's energy sector. Asia Pac Policy Stud 5:558-582. https://doi.org/10.1002/app5.251

Verma M, Loha C, Sinha AN, Chatterjee PK (2017) Drying of biomass for utilising in co-firing with coal and its impact on environment-a review. Renew Sustain Energy Rev 71:732-741. https://doi.org/10.1016/j.rser.2016.12.101

Vijay V, Pimm SL, Jenkins CN, Smith SJ (2016) The Impacts of Oil Palm on Recent Deforestation and Biodiversity Loss. PLoS ONE 11:e0159668. https://doi.org/10.1371/journal.pone.0159668

White S, White N, Middleton G (2006) Report on findings on the proposed Iralalaro Hydor-electric Power Scheme, Timor-Leste. The Haburas Foundation and The Australian Conservation Foundation

Yadav A, Pal N, Patra J, Yadav M (2018) Strategic planning and challenges to the deployment of renewable energy technologies in the world scenario: its impact on global sustainable development. Environ Dev Sustain 37:5149. https://doi.org/10.1007/ s10668-018-0202-3

Yoo Y (ed) (2013) Renewable energy development and environmental justice in Thailand: a case of biomass power plant in Roi-Et Province. In: Conference Proceedings on The 3rd International Conference on International Relations and Development (ICIRD). Bangkok, Thailand.

Yudhicara Y, Bani P, Darmawan A (2015) Geothermal system as the cause of the 1979 landslide tsunami in Lembata Island, Indonesia. Indones J Geosci. https://doi.org/10.17014/ijog.2.2. 91-99

Yuliani EL, Indriatmoko Y, Salim MA, Farid IZ, Muhajir M, Prasetyo LB, Heri V (2000) Biofuel policies and their impacts on local people and biodiversity: a case study from Danau Sentarum. Borneo Research Bulletin 41:109-145

Zimmer A, Jakob M, Steckel JC (2015) What motivates Vietnam to strive for a low-carbon economy? On the drivers of climate policy in a developing country. Energy Sustain Dev 24:19-32. https://doi.org/10.1016/j.esd.2014.10.003

Ziv G, Baran E, Nam S, Rodríguez-Iturbe I, Levin SA (2012) Trading-off fish biodiversity, food security, and hydropower in the Mekong River Basin. Proc Natl Acad Sci U S A 109:5609-5614. https://doi.org/10.1073/pnas.1201423109 